\title{
KARAKTERISTIK INDIVIDU DAN PERILAKU PEDULI LINGKUNGAN : PENGGUNAAN LISTRIK
}

\author{
Okfrisda Sakti ${ }^{1}$, Ni Made Sukartini ${ }^{2}$ \\ 1. Magister Ilmu Ekonomi, Universitas Airlangga Surabaya, \\ 2. Fakultas Ekonomi dan Bisnis, Universitas Airlangga Surabaya,
}

\begin{abstract}
ABSTRAK
Penelitian ini bertujuan untuk menganalisis pengaruh variabel sosial-ekonomi dan demografis, informasi dan pengetahuan pada perilaku peduli lingkungan khususnya pada penggunaan energi listrik. Data yang digunakan adalah Survei Perilaku Peduli Lingkungan Hidup Indonesia (SPPLH) 2013 yang dilakukan oleh Badan Pusat Statistik (BPS). Penelitian ini mengamati perilaku peduli lingkungan, terutama penggunaan listrik, yang berjumlah 70.406 pengamatan. Model regresi logistik digunakan untuk melihat pengaruh variabel bebas terhadap variabel terikat. Hasil penelitian menunjukkan bahwa semakin matang dan semakin berpendidikan individu, maka peluang untuk melakukan tindakan peduli lingkungan menjadi lebih besar. Secara umum individu yang tinggal diperkotaan dan terpapar informasi baik yang berasal dari media maupun secara langsung akan memiliki pengetahuan normatif terkait lingkungan yang lebih baik. Dengan semakin baiknya pengetahuan yang dimiliki terkait lingkungan, maka akan menyebabkan individu tersebut berperilaku peduli lingkungan.
\end{abstract}

Kata kunci: Perilaku Peduli Lingkungan, Listrik, Kesadaran Lingkungan. 


\section{PENDAHULUAN}

Berbicara masalah keberlanjutan (sustainability) tentu tidak dapat dipisahkan dari masalah lingkungan. Pertumbuhan penduduk dan pertumbuhan ekonomi yang tinggi menyebabkan masalah lingkungan menjadi penting untuk diperhatikan. Meningkatnya jumlah penduduk memberikan tekanan terhadap linkungan (Cropper, 1994). Ditambah pandangan antroposentris manusia menjadi penyebab tindakan mal adaptif terhadap lingkungan. Manusia memandang lingkungan sebagai objek ataupun alat yang digunakan untuk memenuhi kebutuhannya.

Pentingnya kepedulian terhadap lingkungan sejalan dengan konsep Sustainable Development Goals (SDG). Konsep SDGs mengharap memperkuat peran sentral faktor lingkungan dan memperlakukan faktor lingkungan sebagai dasar bagi semua hasil pembangunan. Ada kaitan yang erat antara lingkungan dan kegiatan ekonomi (Siebert, 2004). Lingkungan menyediakan bahan baku input produksi dan barang yang dikonsumsi secara langsung seperti air, udara, dan keindahan alam. Penerima efek negatif (receptable waste) dari proses produksi dan konsumsi juga merupakan fungsi dari lingkungan. Terjadinya polusi udara tentu mengancam kesehatan manusia. Adanya perubahan iklim akibat banyaknya emisi yang memicu gas rumah kaca juga merupakan dampak negatif bagi manusia. Kelangkaan sumber daya air, energi sebagai input produksi juga merupakan dampak yang bisa dirasakan manusia.

Indonesia merupakan negara dengan jumlah penduduk yang sangat banyak. Saat ini menduduki negara dengan jumlah penduduk terbanyak keempat didunia dengan 261,9 juta jiwa (BPS, 2018). 68 persen penduduk indonesia merupakan masyarakat dengan kategori miskin atau rentan miskin serta rata-rata berpendidikan rendah (BPS, 2018). Dengan populasi penduduk dan kondisi pendidikan dan pendapatan yang seperti itu, maka Indonesia menghadapi masalah terkait lingkungan. Perilaku masyarakat miskin dan berpendidikan rendah cenderung present oriented (berupaya untuk memenuhi kebutuhan dasarnya terlebih dahulu atau monetary value) daripada kepedulian lingkungan (environmental value) (Stroup, 2016). Adanya pembalakan liar, pencemaran sungai melalui pembuangan 
limbah, pembakan hutan merupakan contoh nyata dari kurangnya kepedulian terhadap lingkungan.

Indonesia adalah penghasil emisi $\mathrm{CO}^{2}$ terbesar se-Asia Tenggara dengan kontributor terbesar dari deforestasi dan penggunaan kendaraan bermotor (Yusuf, 2018). Total deforestasi di Indonesia pada 2014-2015 mencapai 1,09 juta hektar (BPS, 2018). Indonesia juga tercatat sebagai negara penghasil sampah plastik ke laut kedua di dunia setelah Tiongkok dengan rata-rata sampah perkapita mencapai 0,52 Kg (Jambeck, 2015). Permasalahan berikutnya yang dihadapi Indonesia adalah terkait dengan ketersediaan air bersih. Seiring dengan pertambahan populasi manusia dan perilaku yang buruk dalam penggunaan air, air bersih semakin menjadi sumberdaya yang langka dan tidak ada penggantinya. Di tahun 2016, BPS mencatat baru 71,4 persen rumah tangga dengan sumber air minum layak. Kondisi kualitas air sungai pada umumnya berada pada status tercemar berat (BPS, 2018). Untuk sektor listrik, konsumsi listrik Indonesia pada tahun 2018 mencapai 112,46 TeraWatthour (TWh) atau naik sebesar 4,7 persen (cnnindonesia.com). Temuan studi Economy and Environment Program for Southeast Asia oleh Yusuf dan Fransisco tahun 2010 yang menghitung indeks kerentanan perubahan iklim se-Asia Tenggara menemukan bahwa kota-kota di Indonesia (khususnya Jakarta) merupakan daerah yang paling rentan terhadap perubahan iklim. Pada tahun 2014, total emisi GRK Indonesia telah mencapai 1.808 juta ton $\mathrm{CO}^{2}$ e. Angka ini, secara konsisten menunjukkan adanya peningkatan emisi dari tahun 2000-2013 sebesar 3,5 persen per tahun (KLHK, 2015). Sementara, Indonesia menargetkan tahun 2030 untuk menurunkan emisi GRK sebesar 29 persen dengan usaha sendiri atau selanjutnya sampai 41 persen dengan bantuan internasional. Hal ini menjadi dasar perubahan target penurunan emisi GRK dari sebelumnya 26 persen di tahun 2020. Dengan kondisi tersebut dapat diartikan Indonesia saat ini menghadapi tantangan berat dalam hal menjaga kualitas lingkungan dan memelihara kepedulian masyarakat terhadap lingkungan. Sehingga diperlukan langkah-langkah terkait dalam mewujudkan target tersebut, yang salah satunya melalui peningkatan kepedulian masyarakat.

Kepedulian masyarakat tercermin dari perilaku peduli lingkungan yang bisa dilakukan oleh rumah tangga atau pribadi. Beberapa cara yang bisa dilakukan adalah 
dengan mengurangi pemakaian energi listrik, pemakaian air dan penggunaan kendaraan pribadi. Dengan melakukan tindakan peduli lingkungan (contoh:mengurangi penggunaan listrik) maka seseorang dapat merasakan dampak langsung dengan berkurangnya pengeluaran untuk membayar tagihan listrik dan air. Pengurangan pemakaian energi listrik memiliki dampak positif terhadap lingkungan. Kita mengetahui bahwa pasokan listrik berasal dari sumber daya batubara yang sifatnya tidak dapat diperbaharui. Proses produksi listrik juga mengeluarkan emisi karbon yang menyebabkan memanasnya suhu bumi.

Penelitian sebelumnya terkait perilaku peduli lingkungan dan faktor sosiodemograpi telah dilakukan dibeberapa negara. Xiao et al., (2010) melakukan penelitian mengenai perilaku peduli lingkungan pada masyarakat Tiongkok. Dalam penelitiannya Xiao et al., (2010) menggunakan variabel bebas umur, jenis kelamin, pendidikan, pendapatan, status pekerjaan, pengetahuan, dan daerah tempat tinggal. Hasilnya adalah umur, jenis kelamin, pendidikan, pendapatan, pengetahuan, dan daerah tempat tinggal berpengaruh terhadap perilaku peduli lingkungan.

Penelitian ini terfokus pada perilaku yang dilakukan oleh individu dalam ruang pribadi (private sphere) sehingga dapat dilakukan oleh semua orang. Pemilihan perilaku pada kelompok ini dikarenakan kelompok perilaku ini cenderung memiliki konsekuensi lingkungan langsung dan cenderung memiliki dampak yang jauh lebih besar pada lingkungan (Stern, 2000). Fokus perilaku peduli lingkungan masyarakat dalam penelitian ini hanya terbatas pada perilaku penggunaan listrik rumah tangga. Dengan melakukan penelitian pengaruh faktor sosio-ekonomi dan demograpi, informasi dan pengetahuan normatif terhadap perilaku peduli lingkungan masyarakat, maka akan diperoleh gambaran faktor mana saja yang memiliki pengaruh terbesar sehingga dapat digunakan sebagai masukan bagi pemerintah dalam mengambil kebijakan terkait lingkungan. Penelitian ini memiliki beberapa tujuan untuk menjawab isu diantaranya: 1. Bagaimana pengaruh faktor sosio-ekonomi dan demograpi, informasi dan pengetahuan normatif dalam tindakan pengurangan penggunaan listrik rumah tangga? 2. Mengetahui kondisi perilaku penggunaan listrik rumah tangga di Indonesia. 


\section{METODOLOGI}

Data yang digunakan adalah data hasil Survei Perilaku Peduli Lingkungan Hidup Indonesia (SPPLH) tahun 2013 yang dilakukan Badan Pusat Statistik (BPS). SPPLH 2013 dipilih karena mampu menyajikan data yang dibutuhkan seperti (i) karakteristik individu anggota keluarga atau rumah tangga, (ii) karakteristik perumahan, (iii) pemanfaatan energi, (iv) sumber air, (v) pemanfaatan transportasi, (vi) kesadaran lingkungan, dan (vii) pengetahuan, kesadaran dan upaya untuk mengurangi polusi. SPPLH 2013 mempunyai total sampel sebesar 75.000 rumah tangga yang tersebar di 34 provinsi dan 514 kabupaten/kota di Indonesia dengan rumah tangga tercacah sebesar 70.406 rumh tangga.

Variabel terikat yang ditetapkan dalam penelitian ini adalah perilaku peduli lingkungan dalam kegiatan pribadi. Beberapa penelitian terdahulu yang meneliti tentang perilaku peduli lingkungan dalam ruang pribadi dilakukan oleh (Chen, 2011; Xiao, 2010) dinegara China. Responden ditanya apakah mereka melakukan tindakan dalam hal pengurangan penggunaan energi listrik dalam setahun terakhir (1= ya; $0=$ tidak). Variabel bebas yang ditetapkan adalah faktor sosioekonomi meliputi umur (dalam tahun), jenis kelamin (1=laki-laki; $0=$ perempuan), status kawin ( $1=$ belum kawin; $0=$ kawin), pendidikan ( $1=$ Tidak punya ijazah SD; 2=SD/Sederajat; 3= SMP/Sederajat; 4=SMA/Sederajat; 5=D1/D2/D3; 6=D4/S1; 7= $\mathrm{S} 2 / \mathrm{S} 3)$, pendapatan $(1=<500$ ribu rupiah; $2=500 \mathrm{ribu}-1$ juta rupiah; $3=1,1-2,5$ juta rupiah; $4=2,6-5$ juta rupiah; $5=5,1-10$ juta rupiah; $6=>10$ juta rupiah), status pekerjaan $(1=$ bekerja; $0=$ tidak bekerja), daerah tempat tinggal $(1=$ kota; $0=$ desa). Faktor sumber informasi meliputi informasi yang diterima secara langsung ( $1=$ ya; $0=$ tidak $)$ dan informasi yang diterima melalui media ( $1=$ ya; $0=$ tidak), Untuk pengetahuan lingkungan kami mengadopsi penelitian Hong dan Xiao (2007). Variabel ini dibentuk dari 11 pernyataan tentang lingkungan, jawaban benar mendapat nilai satu dan jawaban lainnya tidak mendapat nilai. Nilai tertinggi adalah 11 dan terendah adalah 0 . Untuk pernyataan nomor 2,3,9 merupakan pernyataan negatif sehingga jawaban salah yang mendapat nilai 1 . Contoh penyataan positif "Sinar matahari dapat dijadikan sumber energi listrik alternatif", jawaban normatif adalah "benar". Contoh pernyataan negatif "melakukan perawatan kendaraan 
bermotor tidak ada kaitannya dengan menjaga lingkungan", jawaban normatif adalah "salah".

Penelitian ini merupakan penelitian kuantitatif untuk melihat pengaruh variabel bebas terhadap variabel terikat. Analisis yang digunakan adalah analisis regresi logistik biner. Dalam analisis regresi logistik biner, variabel terikat merupakan variabel dummy yang terdiri dari dua kategori. Regresi logistik biner digunakan untuk melihat peluang terjadinya suatu kejadian yang dipengaruhi oleh karakteristik variabel bebas tertentu. Sedangkan untuk mengetahui peluang terjadinya variabel terikat (dalam hal ini pengurangan penggunaan listrik) yang dipengaruhi karakteristik variabel bebas maka digunakan odds ratio. Pengolahan pada data dengan menggunakan software Stata versi 13. Model dalam penelitian ini adalah sebagaiberikut:

$$
\begin{aligned}
& \ln \left(\frac{P}{1-P}\right)=\beta_{0}+\beta_{1} A g e+\beta_{2} D_{1} \text { Sex }+\beta_{3} D_{2} \text { Kawin }+\beta_{4} E d u c \text { in }+\beta_{5} \text { Incomen }+\beta_{6} D_{3} \text { Kerja }+ \\
& \beta_{7} D_{4} \text { Media }+\beta_{8} D_{5} \text { Langsung }+\beta_{9} D_{6} D t t+\beta_{10} \text { Know }+\varepsilon
\end{aligned}
$$

Dimana:

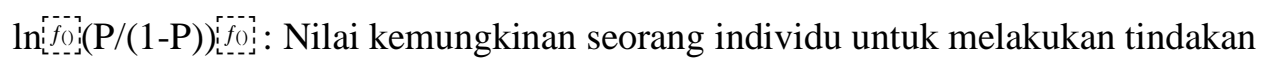
peduli lingkungan dengan syarat kondisi $\mathrm{Xi}$

B0 : konstanta

$\beta \mathrm{i} \quad$ : koefisien regresi

Age : umur

Sex : jenis kelamin

Kawin : status perkawinan

Educ : tingkat pendidikan yang ditamatkan

Income: pendapatan rumah tangga

Kerja : status bekerja

dtt : klasifikasi daerah tempat tinggal

media : informasi yang diperoleh dari media

langsung: informasi yang diperoleh secara langsung

Know : pengetahuan terhadap lingkungan

$\varepsilon \quad:$ error 


\section{HASIL DAN PEMBAHASAN}

Bagian ini membahas tentang ringkasan statistik dari variabel yang digunakan dan hasil estimasi model. Tabel 1 menunjukkan informasi total sampel observasi dalam penelitian ini adalah 70.406 individu yang mewakili informasi rumah tangga. Variabel terikat yaitu kepedulian terhadap penggunaan energi listrik. Menunjukkan variabel biner, nilai satu mengindikasikan bahwa rumah tangga tersebut mengurangi penggunaan listrik setahun terakhir. Dalam hal variabel independen, hampir semua data diukur dalam skala pengukuran non-rasio, kecuali usia responden. Tingkat pendidikan dan pendapatan disajikan dalam skala ordinal, dan pengkodeannya mengikuti standar BPS. Rerata tingkat pendidikan responden adalah 1,734 dengan standar deviasi 1,398. Angka tersebut menyiratkan bahwa ratarata lama responden sekolah adalah antara 6 tahun (sekolah dasar) hingga 9 tahun (sekolah menengah). Di sisi lain, rata-rata tingkat pendapatan adalah 2,71 dengan standar deviasi 1,11. Angka ini menunjukkan rata-rata responden memiliki penghasilan di bawah Rp 1.000.000 per bulan.

Tabel 1. Statistik Deskriptif Variabel Terikat dan Variabel Bebas

\begin{tabular}{|c|c|c|c|c|c|}
\hline No & Variable Description & $\begin{array}{l}\text { No of } \\
\text { Obsv. }\end{array}$ & $\begin{array}{c}\text { Mean and } \\
\text { SD }\end{array}$ & $\begin{array}{c}\text { Minimum } \\
\text { Value }\end{array}$ & $\begin{array}{c}\text { Maximum } \\
\text { Value }\end{array}$ \\
\hline \multicolumn{6}{|c|}{ Dependent Variables } \\
\hline 1 & $\begin{array}{l}\text { Electricity. Value } 1=\text { subjective } \\
\text { report that individual engage in } \\
\text { reducing daily use of electricity; } 0 \\
\text { otherwise }\end{array}$ & 70,406 & $\begin{array}{c}0.362 \\
(0.480)\end{array}$ & 0 & 1 \\
\hline \multicolumn{6}{|c|}{ Individual Characteristics } \\
\hline 2 & Age (years) & 70,406 & $\begin{array}{c}43.693 \\
(14.238)\end{array}$ & 12 & 98 \\
\hline 3 & Sex $(1=$ male $)$ & 70,406 & $\begin{array}{c}0.459 \\
(0.498)\end{array}$ & 0 & 1 \\
\hline 4 & Marital Status (1=married) & 70,406 & $\begin{array}{c}0.2003 \\
(0.4002)\end{array}$ & 0 & 1 \\
\hline 5 & Educational Level & 70,406 & $\begin{array}{c}1.724 \\
(1.398)\end{array}$ & 0 & 6 \\
\hline
\end{tabular}




\begin{tabular}{|c|c|c|c|c|c|}
\hline 6 & Income Level & 70,406 & $\begin{array}{c}2.714 \\
(1.111)\end{array}$ & 1 & 6 \\
\hline 7 & Employment Status (work=1) & 70,406 & $\begin{array}{l}0.643 \\
(0.478)\end{array}$ & 0 & 1 \\
\hline 8 & Dummy location (urban=1) & 70,406 & $\begin{array}{l}0.4221 \\
(0.4939)\end{array}$ & 0 & 1 \\
\hline 9 & Source of Inf. (Self-Knowledge) & 70,406 & $\begin{array}{r}0.6988 \\
(0.4587)\end{array}$ & 0 & 1 \\
\hline 10 & Source of Inf. (Media) & 70,406 & $\begin{array}{l}0.7175 \\
(0.4502)\end{array}$ & 0 & 1 \\
\hline 11 & $\begin{array}{l}\text { Normative Knowledge about } \\
\text { Environmental Issues }\end{array}$ & 70,406 & $\begin{array}{c}6.774 \\
(2.444)\end{array}$ & 0 & 11 \\
\hline
\end{tabular}

Sumber: data diolah 2019

Dari olah variabel pengetahuan (tabel 2) diketahui bahwa 81 persen responden telah mengetahui jika menghemat listrik berarti juga menghemat bahan bakar. Pengetahuan responden tentang sinar matahari yang dapat digunakan sebagai sumber energi alternatif sebesar 77 persen cukup menggembirakan. Baiknya persentase pengetahuan responden tentu harus didukung upaya pemerintah untuk menciptakan kebijakan yang lebih peduli lingkungan. Sosialisasi rumah dengan pencahayaan yang baik dan promosi penggunaan alat berbasis tenaga surya (solar cell) adalah tindakan yang dapat dilakukan. Dengan memaksimalkan pencahayaan sinar matahari disiang hari maka dapat mengurangi penggunaan energi listrik.

Tabel 2. Pernyataan Normatif Untuk Mengukur Pengetahuan Responden

\begin{tabular}{|l|l|c|c|c|c|}
\hline \multirow{2}{*}{ No. } & \multirow{2}{*}{ Pernyataan } & Jawaban normatif & \multicolumn{2}{|c|}{ Persentase jawaban } \\
\cline { 4 - 6 } & & yang diharapkan & Benar & Salah & $\begin{array}{c}\text { Tidak } \\
\text { tahu }\end{array}$ \\
\hline 1 & $\begin{array}{l}\text { Menghemat listrik berarti menghemat bahan } \\
\text { bakar }\end{array}$ & Benar & 81,01 & 5,41 & 13,58 \\
\hline 2 & $\begin{array}{l}\text { Sinar matahari dapat dijadikan sumber } \\
\text { energi listrik alternatif }\end{array}$ & Benar & 77,1 & 3,12 & 19,78 \\
\hline
\end{tabular}

Sumber: olah data 2019 
Berdasarkan olah data (tabel 3) diketahui bahwa semua variabel bebas menunjukkan pengaruh yang signifikan. Tabel 3 kolom 4 menunjukkan nilai odds ratio yaitu nilai peluang dari karakteristik variabel bebas untuk melakukan tindakan pengurangan penggunanaan listrik. Hal pertama yang perlu diperhatikan adalah kesadaran individu tentang lingkungan secara positif terkait dengan usia dan tingkat pendidikan. Sebagai individu yang semakin matang, dan lebih terdidik, kesadaran mereka terhadap lingkungan menjadi lebih baik.

Tabel 3. Hasil Regresi Logistik

\begin{tabular}{|c|c|c|c|}
\hline Variabel Bebas & Simbol & $\boldsymbol{\beta}$ & Odds Ratio \\
\hline (1) & (2) & (3) & (4) \\
\hline Intersep & $\boldsymbol{\beta}_{0}$ & $-1,974 *$ & 0,1469 \\
\hline \multirow[t]{2}{*}{ Jenis kelamin (laki-laki=1) } & Laki-laki & $-0,1651$ & 0,8477 \\
\hline & Perempuan (kategori acuan) & & \\
\hline Umur & Umur responden & 0,0815 & 1,0081 \\
\hline \multirow{3}{*}{$\begin{array}{l}\text { Status perkawinan (belum } \\
\text { kawin/cerai=1) }\end{array}$} & Belum kawin/cerai & $-0,0512$ & 0,9501 \\
\hline & & & \\
\hline & Kawin & & \\
\hline Pendidikan & Status pendidikan responden & 0,9130 & 1,0956 \\
\hline Pendapatan & Pendapatan responden & $-0,0291$ & 0,9712 \\
\hline \multirow[t]{2}{*}{ Daerah tempat tinggal $($ kota=1) } & Kota & 0,1544 & 1,1669 \\
\hline & Desa & & \\
\hline \multirow[t]{2}{*}{ Media (ya=1) } & Memperoleh informasi dari media & 0,4558 & 1,5774 \\
\hline & $\begin{array}{l}\text { Tidak memperoleh informasi dari } \\
\text { media }\end{array}$ & & \\
\hline \multirow[t]{3}{*}{ Langsung $(\mathrm{ya}=1)$} & Memperoleh informasi secara langsung & 0,1913 & 1,2108 \\
\hline & Tidak memperoleh informasi secara & & \\
\hline & langsung & & \\
\hline Pengetahuan & $\begin{array}{l}\text { Tingkat pengetahuan normatif } \\
\text { responden }\end{array}$ & 0,7592 & 1,0788 \\
\hline \multirow[t]{2}{*}{ Status bekerja (bekerja=1) } & Bekerja & $-0,9415$ & 0,9101 \\
\hline & Tidak bekerja & & \\
\hline \multicolumn{4}{|l|}{${ }^{*}$ Signifikan pada $\alpha=5$ persen } \\
\hline \multicolumn{4}{|l|}{ Pseudo R-Square $=7,0$ persen } \\
\hline Jumlah Observasi $=70.406$ & & & \\
\hline
\end{tabular}


Dalam hal jenis kelamin, laki-laki berpeluang 0,8477 lebih rendah dibanding dengan perempuan dalam hal pengurangan penggunaan energi listrik. Dengan kata lain, laki-laki cenderung tidak melakukan kegiatan pengurangan penggunaan energi listrik. Hal itu terjadi karena biasanya laki-laki banyak menghabiskan waktu diluar rumah untuk bekerja dan wanita menghabiskan waktu dirumah untuk mengurus rumah tangga. Mematikan lampu disiang hari serta mematikan peralatan elektronik yang tidak digunakan adalah hal yang dapat dilakukan. Temuan ini bebeda dengan hasil penelitian Xiao dan Hong (2010). Dalam penelitiannya disebutkan bahwa lakilaki di China lebih peduli lingkungan dibanding perempuan. Hal itu terjadi karena laki-laki di China memiliki pendidikan yang relatif lebih baik dibanding perempuan.

Semakin bertambahnya usia juga semakin meningkatkan kesadaran dalam berperilaku peduli lingkungan. Dengan bertambahnya usia responden maka akan meningkatkan peluang melakukan kegiatan pengurangan penggunaan energi listrik sebesar 0,9501. Tingkat kedewasaan dan kemampuan mengolah informasi terkait pengurangan penggunaan listrik memberikan kesadaran dalam berperilaku peduli lingkungan.

Pengaruh pendidikan terhadap kegiatan pengurangan penggunaan listrik adalah positif. Hasil olah data didapatkan dengan adanya pendidikan yang lebih baik cenderung meningkatkan peluang untuk melakukan perilaku peduli listrik sebesar 1,0956 poin. Pendidikan memainkan peran penting karena mungkin tidak hanya memfasilitasi pemahaman masyarakat tentang masalah lingkungan tetapi juga meningkatkan pengetahuan normatif lingkungan masyarakat. Hasil ini mengonfirmasi temuan Xiao dan Hong (2010), dimana tingkat pendidikan yang lebih tinggi dikaitkan dengan perilaku yang lebih peduli lingkungan..

Yang menarik dari penelitian ini diketahui bahwa saat ada kenaikan pendapatan maka seseorang cenderung tidak berperilaku peduli lingkungan. Adanya kenaikan pendapatan menurunkan peluang melakukan kegiatan pengurangan penggunaan energi listrik sebesar 0,9817. Temuan ini menegaskan perbedaan hasil pengaruh variabel pendapatan terhadap perilaku peduli lingkungan dalam penelitian yang telah dilakukan sebelumnya. Kavousian et al. (2013) tidak menemukan hubungan antara pendapatan dan konsumsi listrik. Beberapa penelitian sebelumnya 
menemukan bahwa rumah tangga dengan pendapatan yang lebih tinggi lebih cenderung berada dalam kategori konsumen listrik (daya) yang tinggi (Jones, 2015), atau mengkonsumsi lebih banyak listrik. Rumah tangga dengan pendapatan yag tinggi cenderung memiliki lebih banyak alat elektronik, sehingga sulit untuk mengurangi penggunaan listrik mereka.

Seseorang yang tinggal didaerah perkotaan cenderung berperilaku peduli lingkungan terhadap kegiatan pengurangan penggunaan listrik rumah tangga. Seseorang yang tinggal diperkotaan berpeluang melakukan kegiatan pengurangan penggunaan energi listrik sebesar 1,1169 dibanding seseorang yang tinggal diperdesaan. Kemudahan akses informasi dan layanan diperkotaan bisa menjadi penyebab mengapa responden yang tinggal diperkotaan lebih berperilaku peduli lingkungan. Biaya hidup yang relatif tinggi juga membuat masyarakat diperkotaan lebih peduli terhadap penggunaan listrik mereka. Namun penelitian di China yang dilakukan Chen et al (2011) menemukan bahwa masyarakat perkotaan kurang peduli lingkungan. Rajecki (1982) menjelaskan perbedaan hal itu dengan membandingkan adanya pengaruh pengalaman langsung dan tidak langsung. Pengalaman merasakan banjir diwilayah perdesaan sekitar aliran sungai membuat masyarakat perdesaan lebih peduli lingkungan.

Adanya sumber informasi yang berasal dari media dan secara langsung memiliki pengaruh positif terhadap pengurangan penggunaan listrik. Peran media dalam mempromosikan alat yang rendah energi juga memainkan peranan dalam membuat masyarakat untuk lebih peduli terhadap pengurangan pemakaian energi listrik. Sebagai contohnya lampu LED dan televisi LED mampu mengurangi pemakaian listrik rumah tangga. Barang-barang ramah energi tersebut memang memiliki harga yang relatif lebih mahal, namun memiliki keunggulan dari lama pemakaian (efisien) dan efek positif dari pengurangan tagihan listrik rumah tangga (ekonomis). Informasi tentang adanya pemanasan global yang salah satunya diakibatkan oleh konsumsi listrik yang berlebihan juga membuat masyarakat lebih peduli terhadap penggunaan listrik. Model awal tentang pengetahuan lingkungan akan mempengaruhi perilaku peduli lingkungan sesuai dengan apa yang ditemukan 
Kollmuss (2002). Dikatakan bahwa pengetahuan lingkungan akan mempengaruhi tindakan dan perilaku peduli lingkungan

Status bekerja juga memiliki pengaruh negatif terhadap kegiatan pengurangan penggunaan listrik rumah tangga. Responden yang bekerja memiliki peluang lebih rendah dalam hal melakukan kegiatan pengurangan penggunaan energi listrik sebesar 0,9101 dibanding responden yang tidak bekerja. Adanya tambahan penghasilan dengan bekerja menyebabkan seseorang dapat membeli peralatan elektronik yang digunakan untuk memenuhi kepuasannya. Mereka rela membayar tagihan listrik yang lebih tinggi asalkan tidak mengurangi kepuasannya.

\section{KESIMPULAN}

Studi ini menyelidiki penentu karakteristik individu pada penggunaan energi listrik. Studi ini menemukan bahwa kesadaran individu sejalan dengan tingkat dan usia pendidikannya. Individu yang berpendidikan dan matang lebih sadar untuk mengkonsumsi sumber daya ekonomi (listrik) lebih efisien. Responden perkotaan juga mengkonsumsi listrik dengan lebih bijaksana dibandingkan responden pedesaan. Pada kegiatan sehari-hari, responden perkotaan melaporkan bahwa mereka menggunakan listrik seefisien mungkin.

Implikasi kebijakan yang mungkin untuk temuan penelitian ini sebagai berikut. Pertama, perlu menyebarkan pengetahuan dan kesadaran tentang masalah lingkungan dan mempraktikkan konsumsi dan produksi yang efisien. Temuan penelitian ini jelas menunjukkan bahwa kesadaran responden berhubungan positif dengan tingkat pendidikan dan informasi yang diterima. Pemerintah harus mengupayakan informasi bagi masyarakat baik itu melalui media maupun yang bersifat langsung. Karena ada kaitan yang erat antara informasi yang diterima masyarakat terkait perilaku peduli lingkungan dengan pengetahuan sehingga berimplikasi terhadap perilaku peduli lingkungan masyarakat. Munculnya sekolah berwawasan lingkungan (adiwiyata) juga mampu memberikan pengaruh positif terhadap perilaku masyarakat di kemudian hari. Kedua, respon perilaku konsumen perkotaan merespons dengan watt listrik yang lebih tinggi. Di Indonesia, semakin tinggi watt listrik, semakin mahal tarifnya. Daerah perkotaan rata-rata menggunakan 
watt listrik yang lebih tinggi. Ini menyiratkan, strategi penetapan harga dapat diterapkan untuk menegakkan sumber daya ekonomi yang dikonsumsi konsumen secara efisien. Penetapan harga progresif untuk listrik harus diterapkan untuk konsumen yang mengkonsumsi jumlah di atas jumlah konvensional per kapita. Konsumen yang mengkonsumsi jumlah per kapita konvensional di atas berarti menikmati kualitas premium. Strategi penetapan harga yang progresif untuk listrik, di samping meningkatkan konsumsi yang efisien juga memungkinkan untuk subsidi silang.

Sebagai penelitian awal tentang bagaimana faktor sosiodemograpi mempengaruhi perilaku penggunaan listrik rumah tangga di Indonesia, tentu saja penelitian ini memiliki kelemahan dan keterbatasan. Dari segi data, data yang disajikan hanyalah data cross section (satu titik waktu) sehingga tidak ada data lain yang dapat digunakan sebagai perbandingan. Dari segi variabel yang dianalisis, disarankan untuk menambahkan variabel lainnya yang belum dimasukkan dalam penelitian ini seperti jumlah anggota rumah tangga, dan berapa anggota rumah tangga yang bekerja sehingga bisa diketahui bagaimana pengaruh struktur rumah tangga juga dapat mempengaruhi perilaku penggunaan listrik rumah tangga. Penambahan variabel perubahan harga tarif dasar listrik juga menarik untuk dianalisis. Melihat pola konsumsi listrik rumah tangga dengan analisis kluster juga dapat dilakukan di analisis berikutnya.

\section{DAFTAR PUSTAKA}

BPS. (2018). Statistik Indonesia 2018. Jakarta. Badan Pusat Statistik. (2018). Statistik Lingkungan Hidup Indonesia 2017. Jakarta. Badan Pusat Statistik. . (2014). Kajian Indikator Sustainable Development Goals. Jakarta. Badan Pusat Statistik. 
Chen, X., Peterson, M.N., \& Hull, Vanessa. (2010). Effects of Attitudinal and Sociodemographic Factors on Pro-environmental Behaviour in Urban China. Environmental Conservation, 38(1), 45-52.

Cropper, M., \& Griffiths, C. (1994). The interaction of population growth and environmental quality. The American Economic Review, 84(2), 250-254.

ESDM. (2018). Statistik Ketenagalistrikan Indonesia 2017. Jakarta. Direktorat Jendral Ketenagalistrikan.

Jambeck, J.R., Andrady, A., Geyer, R., Narayan, R., Perryman, M., Siegler, T., Wilcox, C., Lavender Law, K. , (2015). Plastic waste inputs from land into the ocean, Science, 347, p. 768-771.

Jones RV, Lomas KJ. (2015) Determinants of high electrical energy demand in UK homes: socio-economic and dwelling characteristics. Energy Build;101:2434.

Kavousian A, Rajagopal R, Fischer M. (213). Determinants of residential electricity consumption: using smart meter data to examine the effect of climate, building characteristics, appliance stock, and occupants' behaviour. Energy; 55:184-94.

Kollmuss, A., \& Agyeman, J. (2002). Mind the gap: why do people act environmentally and what are the barriers to pro-environmental behavior?. Environmental education research, 8(3), 239-260.

Rajecki, D. W. (1982). Attitudes: themes and advances. Sunderland, MA.

Siebert, H. (2004). Economics of the Environment (pp. 16-17). Lexington, Berlin: Springer

Stroup, R. L. (2016). Eco-nomics: What Everyone Should Know About Economics and the Environment. Washington DC. Cato Institute.

Stern, P.C., Dietz, T. \& Kalof, L. (1993) Value Orientations, Gender,and Environmental Concern. Environment and Behavior 25(5), 322-348. 
Xiao, C. \& Hong, D. (2010). Gender Differences in Environmental Behaviors in China. Population and Environment, 32(1), 88-104.

Yusuf, Arief Anshory \& Herminia Francisco, Hotspots! Mapping Climate Change Vulnerability in Southeast Asia, 2010, Economy and Environment Program for Southeast Asia, Singapore. ISBN: 978-981-08-6293-0. 